\title{
Health care professionals' neckties as a source of transmission of bacteria to patients: a systematic review
}

\author{
Pia Pace-Asciak MD, Sanjiv K. Bhimrao DM, Frederick K. Kozak MD, Brian D. Westerberg MD
}

Abstract

Background: There is growing concern that neckties worn by health care professionals may contribute to infections contracted in health care settings. We evaluated the evidence for health-care-associated infections resulting from neckties and whether the evidence is sufficient to warrant a tieless policy in Canada.

Methods: We performed a systematic review to determine whether neckties worn by health care professionals colonize harmful pathogenic bacteria and whether they contribute to the spread of infection to patients in the inpatient or outpatient setting. We searched PubMed (1966 to 2017) and Embase (1974 to 2017). The level of evidence was appraised according to the Oxford Centre for Evidence-Based Medicine levels of evidence. We evaluated the quality of evidence and the risk of bias using the Jadad scale or the Newcastle-Ottawa Scale.

Results: We screened 1675 citations, of which 6 were ultimately included in the systematic review. Only 1 study gave level $1 \mathrm{~b}$ evidence (randomized controlled trial). Neckties were more likely than shirt pockets to colonize bacteria. There is limited evidence that neckties may be contaminated with pathogenic bacteria (e.g., methicillin-resistant Staphylococcus aureus) and very limited evidence that contaminated neckties may transmit bacteria (in a controlled experimental setting to a mannequin).

Interpretation: There is no evidence of increased rates of health-care-associated infections related to the wearing of neckties by health care professionals. There is weak evidence that neckties are contaminated with pathogenic (and nonpathogenic) bacteria. The level of evidence was weak and the studies were heterogeneous. Evidence to support the need for a tieless dress code policy is lacking.

Tisas $\mathrm{t}$ is estimated that health care workers, patients and visitors are responsible for spreading about $80 \%$ of common infections contracted in health care settings. ${ }^{1}$ The overall annual direct medical cost to US hospitals of health-careassociated infections has been estimated at US\$28.4 billion to US $\$ 45.0$ billion. Based on estimates of the effectiveness of possible infection control interventions, the predicted benefit of prevention of these infections ranges from US\$5.7 billion to US\$31.5 billion. ${ }^{2}$ There is no reason to expect the proportional costs in Canada to be different. More than 200000 patients annually contract infections while receiving health care in Canada, and more than 8000 of these patients die as a result of these infections. ${ }^{1}$

The World Health Organization acknowledges that this is a worldwide problem. ${ }^{3}$ Any identifiable factor that could be modified to lower the risk of health-care-associated infection should be addressed. To reduce rates of these infections, the proper infrastructure and guidelines within hospitals need to be in place to ensure that enough attention is paid to hygiene, with proper training of health care workers and sterilization of equipment so that modern health care treatment is possible. ${ }^{3}$

Concerned that certain work attire worn by physicians might be a potential vector responsible for increasing the incidence of health-care-associated infections, the UK
Department of Health introduced a Uniforms and Workwear dress code for National Health Service employees in 2007. ${ }^{4}$ This policy has since become known as the "bare-below-theelbow" attire policy as a means for reducing the spread of nosocomial infections. It was recommended that National Health Service staff wear short sleeves and avoid unnecessary jewellery and garments such as neckties when carrying out clinical activities. ${ }^{4}$ No evidence was cited to support the recommendation against the wearing of ties.

If the wearing of neckties increases the risk of health careassociated infections, such a policy restricting their use by health care professionals in Canada (and elsewhere) would be warranted. We performed a systematic review of the published literature to measure the evidence that health care professionals who wear neckties colonize harmful pathogenic bacteria

Competing interests: None declared.

This article has been peer reviewed.

Correspondence to: Brian Westerberg, bwesterberg@ providencehealth.bc.ca

CMAJ Open 2018. DOI:10.9778/cmajo.20170126 
and whether this contributes to the spread of infection to their patients in the inpatient or outpatient setting.

\section{Methods}

\section{Search strategy}

We performed a systematic review according to the PRISMA guidelines. ${ }^{5}$ We searched PubMed (1966 to Nov. 7, 2017) and Embase (1974 to Nov. 7, 2017) using an a priori determined search strategy. We consulted a senior librarian from the College of Physicians and Surgeons of British Columbia medical library to assist with the literature searches.

The literature search identified a main database of articles using the following search strategy: ("infection" [MESH] OR "communicable diseases" [MESH] OR infect* OR communicable*) AND ("health personnel" [MESH] OR "physicians" [MESH] OR physician* OR doctors OR doctor) AND ("clothing"[MESH] OR "attire"[All Fields] OR necktie*) (Appendix 1, available at www.cmajopen.ca/content/6/1/ E26/suppl/DC1). We included papers that were primary studies that examined neckties; editorials and letters were excluded, although we reviewed any references. The search was limited to articles in humans and those published in English. Articles examining potential vectors such as identification badges, stethoscopes and bow ties were excluded unless the comparison was against neckties.

\section{Study selection, quality assessment and data extraction}

Two authors (P.P.-A. and S.K.B.) independently conducted individual reviews of titles and abstracts identified in the literature search. Duplicates were removed with the use of RefWorks (ProQuest). Discrepancies were resolved by discussion via review of the data. Data were extracted by the same 2 researchers who conducted the study selection to ensure consistency of reporting. Discrepancies were handled in a similar manner as for study identification. The following information was extracted from the papers that met our inclusion criteria: study design, setting (inpatient or outpatient), number of patients, number and specialty of the health care workers wearing the ties, bacteria isolated, comparison made, effect on patient or outcome, and level of evidence.

We used the Oxford Centre for Evidence-Based Medicine recommendations ${ }^{6}$ (Table 1 ) to assist in grading the level of evidence in the papers that fit our inclusion criteria. We assessed the full-text articles for study quality and risk of bias using the Jadad scale ${ }^{7}$ and the Newcastle-Ottawa Scale. ${ }^{8}$ The former is the most widely used scale to assess the quality and the risk of bias of clinical trials. It is a 5-point system that assesses the methods used in the clinical trial based on random assignment, double-blinding and the flow of patients. The Newcastle-Ottawa Scale is used to assess the quality, including potential bias, of nonrandomized trials. The more stars (maximum 9), the better the quality of the article.

A meta-analysis was not possible given the heterogeneity of the study population and the small size and poor quality of the

\begin{tabular}{|ll|}
\hline $\begin{array}{l}\text { Table 1: Oxford Centre for Evidence-Based Medicine levels } \\
\text { of evidence }\end{array}$ \\
\hline $\begin{array}{l}\text { Level of } \\
\text { evidence }\end{array}$ & \multicolumn{1}{c|}{ Study design } \\
\hline $1 \mathrm{a}$ & Systematic review of randomized controlled trial \\
\hline $1 \mathrm{~b}$ & Randomized controlled trial \\
\hline $1 \mathrm{c}$ & Case series \\
\hline $2 \mathrm{a}$ & Systematic review of cohort studies \\
\hline $2 \mathrm{~b}$ & Individual cohort study (retrospective) \\
\hline $2 \mathrm{c}$ & Outcomes research/ecological studies \\
\hline $3 a$ & Systematic review of case-control studies \\
\hline $3 \mathrm{~b}$ & Individual case cohort study \\
\hline 4 & Case series and case-control studies \\
\hline 5 & Expert opinion \\
\hline
\end{tabular}

studies. Thus, given the paucity of the evidence, formal statistical analysis was not possible. Had the data been robust, we would have performed a meta-analysis.

\section{Results}

The initial search identified 1675 abstracts in PubMed and Embase (Figure 1). After duplicates were removed, 1418 abstracts remained. On screening, 1374 titles were excluded as not relevant based on our inclusion and exclusion

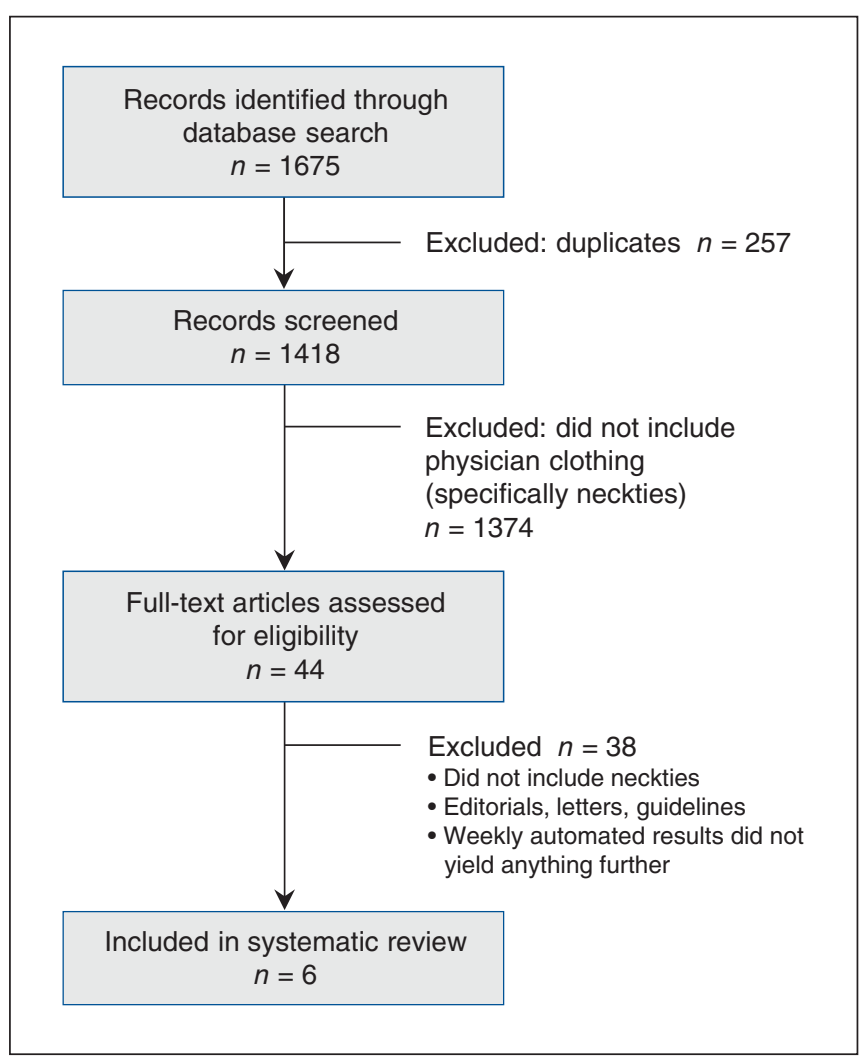

Figure 1: Flow chart showing outcome of search strategy. 
criteria. Forty-four full-text articles remained, which were assessed for eligibility. Six articles were identified that satisfied our inclusion criteria (Table 2). No study specifically assessed the likelihood that wearing a necktie would increase the risk of transmitting an infection to patients directly.

The highest-quality paper (the only study with level $1 \mathrm{~b}$ evidence [Jadad score 3/5]) was a multicentre randomized blinded trial comparing the difference in contamination between bow ties versus neckties worn for 3 days by gynecologists and obstetricians. ${ }^{9}$ The physicians were randomly assigned to groups, but the main weakness of the study was the lack of mention as to whether the investigators were blinded to which tie was worn first; the effect, if any, this may have had on the study results is not in debate. Overall, the study revealed no difference in contamination rates between bow ties and neckties, and none of the bacteria found contaminating either type of tie were thought to be "potentially highly pathogenic."

Four of the studies gave level $3 \mathrm{~b}$ evidence. ${ }^{10-13}$ Lopez and colleagues, ${ }^{10}$ in a prospective study, found higher bacterial counts on neckties than on the front shirt pockets of 50 doctors (25 surgeons and 25 other physicians). Staphylococcus aureus was isolated from items of 16 doctors: 8 shirts (0-11 colony-forming units) and 13 ties (0-86 colony-forming units). Most of the physicians had never cleaned their tie or could not remember when it was laundered last. Among the 14 who could recall, the mean time was 73 days, compared to less than 2 days for laundering their shirt. The NewcastleOttawa Scale score assigned to this study was $7 / 9$, with a reasonable quality design. The paper fell short in reporting the adequacy of cohort follow-up.

In a cross-sectional study, Koh and colleagues ${ }^{11}$ found that neckties worn by doctors were more likely to be contaminated than neckties worn by preclinical medical undergraduates who were not involved in patient care: 26 of the 50 physician neckties were contaminated with $S$. aureus, compared to 14 of 50 ties of the preclinical medical students. In 16 of the physician cases $(62 \%)$, the organism was identified as methicillinresistant $S$. aureus (MRSA). None of the preclinical students' ties were contaminated with MRSA, and 10 of the 14 S. aureus specimens were presumably coagulase-negative (4 were reported as coagulase-positive). The assigned NewcastleOttawa Scale score was 7/9.

In a case-control study, Pisipati and colleagues ${ }^{12}$ investigated the likelihood of contamination with important pathogenic bacteria of new neckties and pens given to 4 urological surgeons each week for 5 consecutive weeks. Only common

Table 2: Summary of the 6 studies included in the systematic review

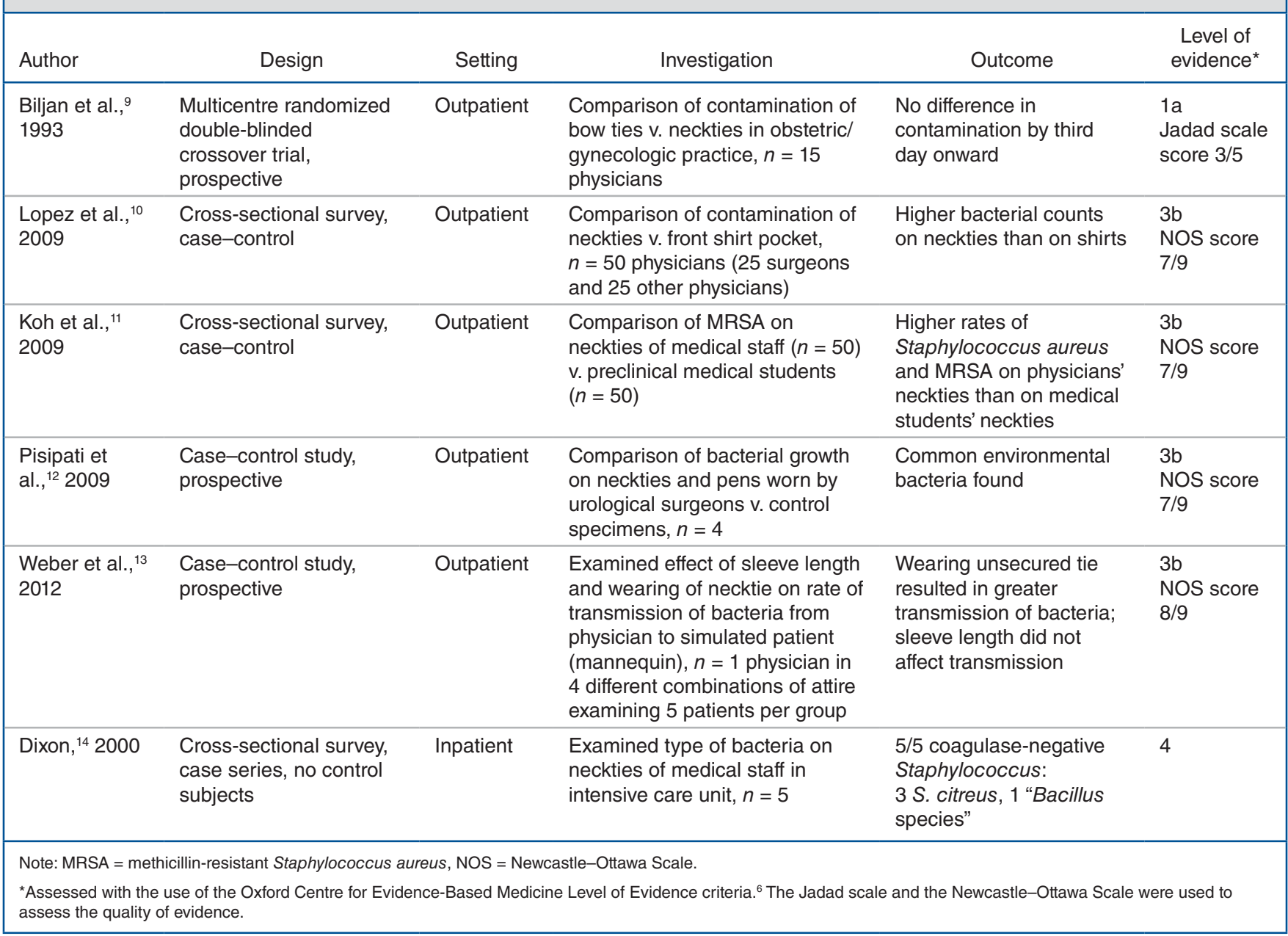


environmental contaminants were found, and no "important pathogenic bacteria" were identified. The assigned NewcastleOttawa Scale score was 7/9.

Finally, Weber and colleagues ${ }^{13}$ found in their prospective experimental study that simulated patient encounters during which an unsecured tie was worn were associated with bacterial contamination of more mannequins than encounters where an unsecured tie was not worn. The assigned Newcastle-Ottawa Scale score was 8/9.

One study gave level 4 evidence. In a cross-sectional survey, growth of coagulase-negative Staphylococcus was reported from all 5 neckties of doctors in the intensive care unit. ${ }^{14}$ Heavy growth was found for 2 of the neckties. S. citreus was identified on 3 ties (heavy growth on 1), and "Bacillus species" was identified on 1 tie. These organisms are not usually considered to be pathogenic in immunocompetent patients.

\section{Interpretation}

There is evidence that neckties worn by health care professionals are often contaminated with nonpathogenic bacteria commonly found on the skin and in the environment, as presumably is any article of clothing. There is very limited evidence that neckties may be contaminated more often with pathogenic bacteria (e.g., MRSA) and that contaminated neckties transmit bacteria in a controlled experimental setting (to a mannequin). Despite this, there is evidence neither that a health care professional who wears a necktie is responsible for increased rates of health-care-associated infections nor that restricting health care professionals from wearing neckties will decrease the rate of occurrence of such infections. One may infer from 1 study with level $3 \mathrm{~b}$ evidence ${ }^{13}$ that securing a necktie to avoid patient contact is advised, but there is limited evidence that contact of a necktie with a patient will lead to infection. Further research is needed to look at whether neckties or other pendulous objects such as stethoscopes and lanyards transmit bacteria or lead to infection in patients. With the current evidence available, the likelihood that a necktie with any pathogen poses risk to a patient is negligible.

The UK bare-below-the-elbow dress code policy has been openly questioned. ${ }^{15,16}$ Nonetheless, the policy was updated in 2010, with comparable recommendations. ${ }^{17}$ The updated policy similarly concludes that it is considered poor practice to wear neckties (other than bow ties) or lanyards during activities involving direct patient care. Evidence supporting the recommendation against the wearing of ties was once again not cited; instead it was referenced as "common sense."

Regular handwashing has been shown to reduce hospitalacquired infections. ${ }^{18}$ Outbreak reports and observational studies looking at the dynamics of hand contamination have shown an association between activities that involve direct patient contact and hand contamination. ${ }^{18}$ Some studies have shown that removal of rings results in a decreased frequency of hand carriage of pathogens before and after performing hand hygiene. ${ }^{18,19}$ However, in a prospective study of 93 physicians, Willis-Owen and colleagues ${ }^{20}$ did not find a statistically significant difference in the number of colony-forming units of bacteria or in the presence of clinically significant organisms found between physicians who complied with the bare-below-the-elbows policy and those who did not. Other pendulous objects that are worn by physicians, such as stethoscopes and identification badges, have also been considered. ${ }^{21,22}$ Lanyards and identification badges can carry pathogenic bacteria such as MRSA, methicillin-sensitive $S$. aureus, Enterococcus species and gram-negative bacteria. ${ }^{22}$

Although there is a lack of evidence confirming that neckties are responsible for health-care-associated infections, sensibility should prevail. The Society for Healthcare Epidemiology of America prudently recommends that, rather than a ban on neckties, neckties should be secured by a laboratory coat or a tie clip to prevent the tie from coming into contact with the patient. ${ }^{23}$ Similar logic should be applied to other pendulous objects that are worn by physicians. ${ }^{21,22}$

The necktie is an icon of male professionalism and has been worn by male physicians for over 100 years. Other clothing, such as the white coat, has been the most recognized symbol representing power and purity since the 19th century, when Lister was developing his concept of aseptic surgery. ${ }^{24}$ In essence, dress codes play an important role in nurturing the patient-physician relationship and instilling confidence in patients that they are receiving the highest-quality care. Rehman and colleagues ${ }^{25}$ found that $76.3 \%$ of patients preferred their physician to be clothed in professional attire, i.e., shirt, necktie and white coat for male physicians, and tailored trouser or skirt with white coat for female physicians. Respondents' trust, confidence and willingness to share personal information were greater for a physician in professional attire. Hence, recommendations against the wearing of a necktie are not without consequences.

\section{Limitations}

One of the limitations of our study is that formal statistical analysis was not possible. The data available in the literature were heterogeneous and were evaluated qualitatively by validated methods versus quantitatively through meta-analysis. Second, our literature search set limits to articles published in English. However, none of the references cited in the barebelow-the-elbow policy study ${ }^{4}$ were in languages other than English, and, in general, exclusion of non-English-language articles has been found not to have a significant impact on the results of systematic reviews. ${ }^{26}$

\section{Conclusion}

There is a lack of evidence to suggest that the wearing of neckties by health care professionals contributes to a higher rate of health-care-associated infections. The wearing of a necktie by a health care professional is a symbol evoking trust and confidence for a patient. Simple measures to avoid patient contact by the necktie seem prudent, but the available evidence does not support a nation-wide policy restricting their use. However, the data are sparse. If concerns remain regarding the wearing of neckties, a larger prospective study is required before a nation-wide policy against their use is implemented in Canada. 


\section{References}

1. The Chief Public Health Officer's report on the state of public health in Canada 2013 — healthcare-associated infections — due diligence. Ottawa: Public Health Agency of Canada; [modified 2013]. Available: www.phac-aspc.gc.ca/ cphorsphc-respcacsp/2013/infections-eng.php (accessed 2017 Jan 2).

2. Scott RD 2nd. The direct medical costs of healthcare-associated infections in U.S. hospitals and the benefits of prevention. Atlanta: Centers for Disease Control and Prevention; 2009. Available: http://stacks.cdc.gov/view/cdc/11550 (accessed 2014 Oct. 7).

3. Report on the burden of endemic health care-associated infection worldwide: clean care is safer care. Geneva: World Health Organization; 2011. Available: apps.who.int/ iris/bitstream/10665/80135/1/9789241501507_eng.pdf (accessed 2017 Sept. 18).

4. Jacob J. Uniforms and workwear: an evidence base for developing local policy. Leeds (UK): Department of Health, National Health Service; 2007. Available: webarchive.nationalarchives.gov.uk/20130220145219/http://www.dh.gov.uk/ prod_consum_dh/groups/dh_digitalassets/documents/digitalasset/dh_078435 .pdf (accessed 2014 Oct. 5).

5. Liberati A, Altman DG, Tetzlaff J, et al. The PRISMA statement for reporting systematic reviews and meta-analyses of studies that evaluate health care interventions: explanation and elaboration. PLoS Med 2009;6:e1000100.

6. Levels of evidence (March 2009). Oxford (UK): Centre for Evidence-Based Medicine; 2009. Available: www.cebm.net/blog/2009/06/11/oxford-centre-evidence -based-medicine-levels-evidence-march-2009/ (accessed 2018 Jan. 2).

7. Jadad AR, Moore RA, Carroll D, et al. Assessing the quality of reports of randomized clinical trials: Is blinding necessary? Control Clin Trials 1996;17:1-12.

8. Wells GA, Shea B, O'Connell D, et al. The Newcastle-Ottawa Scale (NOS) for assessing the quality of nonrandomised studies in meta-analyses. Ottawa: Ottawa Hospital Research Institute; 2014. Available: www.ohri.ca/programs/ clinical epidemiology/oxford.asp (accessed 2017 Sept. 18).

9. Biljan MM, Hart CA, Sunderland D, et al. Multicentre randomised double blind crossover trial on contamination of conventional ties and bow ties in routine obstetric and gynecological practice. BM7 1993;307:1582-4.

10. Lopez PJ, Ron O, Parthasarathy P, et al. Bacterial counts from hospital doctors' ties are higher than those from shirts. Am $\mathcal{F}$ Infect Control 2009;37:79-80.

11. Koh KC, Husni S, Tan JE, et al. High prevalence of methicillin-resistant Staphylococcus aureus (MRSA) on doctors' neckties. Med 7 Malaysia 2009;64:233-5.

12. Pisipati S, Bassett D, Pearce I. Do neckties and pens act as vectors of hospitalacquired infections? BfU Int 2009;103:1604-5.

13. Weber RL, Khan PD, Fader RC, et al. Prospective study on the effect of shirt sleeves and ties on the transmission of bacteria to patients. 7 Hosp Infect 2012; 80:252-4.

14. Dixon M. Neck ties as vectors for nosocomial infection [letter]. Intensive Care Med 2000;26:250.

15. Bond L, Clamp PJ, Gray K, et al. Patients' perceptions of doctors' clothing: Should we really be 'bare below the elbow'? 7 Laryngol Otol 2010;124:963-6.

16. The Health Act 2006: code of practice for the prevention and control of healthcare associated infections. London (UK): Department of Health; [revised 2008].

17. Uniforms and workwear: guidance on uniform and workwear policies for NHS employees. Leeds (UK): Department of Health; 2010. Available: webarchive. nationalarchives.gov.uk/20130107105354/http:/www.dh.gov.uk/prod_consum_ dh/groups/dh_digitalassets/@dh/@en/@ps/documents/digitalasset/dh_114754. pdf (accessed 2014 Oct. 5).

18. Loveday HP, Wilson JA, Pratt RJ, et al. epic3: national evidence-based guidelines for preventing healthcare-associated infections in NHS hospitals in England. 7 Hosp Infect 2014;86(Suppl 1):S1-70.

19. Trick WE, Vernon MO, Hayes RA, et al. Impact of ring wearing on hand contamination and comparison of hand hygiene agents in a hospital. Clin Infect Dis 2003;36:1383-90.

20. Willis-Owen CA, Subramanian P, Kumari P, et al. Effects of 'bare below the elbows' policy on hand contamination of 92 hospital sectors in a district general hospital. 7 Hosp Infect 2010;75:116-9.

21. Breathnach AS, Jenkins DR, Pedler SJ. Stethoscopes as possible vectors of infection by staphylococci. BM7 1992;305:1573-4.

22. Kotsanas D, Scott C, Gillespie EE, et al. What's handing around your neck? Pathogenic bacteria on identity badges and lanyards. Med 7 Aust 2008;188: $5-8$.

23. Bearman G, Bryant K, Leekha $S$, et al. Healthcare personnel attire in nonoperating-room settings. Infect Control Hosp Epidemiol 2014;35:107-21.

24. Blumhagen DW. The doctor's white coat. Ann Intern Med 1979;91:111-6.

25. Rehman SU, Nietert PJ, Cope DW, et al. What to wear today? Effect of doctor's attire on the trust and confidence of patients. Am 7 Med 2005;118: 1279-86.

26. Moher D, Pham B, Klassen TP, et al. What contributions do languages other than English make on the results of meta-analyses? 7 Clin Epidemiol 2000;53: 964-72.

Affiliations: Division of Otolaryngology (Pace-Asciak), Royal Inland Hospital, Kamloops, BC; Department of Otolaryngology (Bhimrao), University Hospital of North Midlands NHS Trust, Royal Stoke University Hospital, Stoke on Trent, Staffordshire, UK; Division of Otolaryngology (Kozak), BC Children's Hospital; BC Rotary Hearing and Balance Centre at St. Paul's Hospital (Westerberg), University of British Columbia, Vancouver, BC

Contributors: Brian Westerberg and Frederick Kozak conceived and designed the study. Pia Pace-Asciak acquired the data and drafted the manuscript. Pia Pace-Asciak and Sanjiv Bhimrao contributed to data analysis and interpretation. All of the authors revised the manuscript for important intellectual content, gave final approval of the version to be published and agreed to be accountable for all aspects of the work.

Acknowledgement: The authors acknowledge the contributions of Karen MacDonell from the College of Physicians and Surgeons of British Columbia medical library in performing the literature search.

Supplemental information: For reviewer comments and the original submission of this manuscript, please see www.cmajopen.ca/content/6/1/ E26/suppl/DC1. 